FACTA UNIVERSITATIS

Series: Philosophy, Sociology, Psychology and History Vol. 16, Nº 3, 2017, pp. 185 - 199

https://doi.org/10.22190/FUPSPH1703185N

\title{
LEIBNIZ'S MIRROR THESIS. SOLIPSISM, PRIVATE PERSPECTIVES AND CONCEPTUAL HOLISM
}

\author{
UDC 165.321
}

\author{
Antonio Maria Nunziante \\ University of Padova, Department of Philosophy, Sociology, Education \\ and Applied Psychology, Italy
}

\begin{abstract}
One of the symbolic images to which Leibniz constantly entrusted the synthesis of his philosophy regards the idea of considering one and the same city from various visual perspectives. Such an image is diffused throughout all Leibniz's writings and clearly reflects the philosopher's interest for matters regarding perspective as well as optical phenomena. The point of view of its inhabitants can therefore be compared to a mirror that reflects some different portions of reality. But what do the city-viewers really see? Do they all see exactly the same thing? And assuming the plurality of points of view, how one can be sure that they share the same representative content? The paper presented here tries to offer a plausible interpretation of this topic also by linking different and somehow remote Leibnizian doctrines together.
\end{abstract}

Key words: Leibniz, Mind, Solipsism, Perspective, Perception, Holism.

\section{INTRODUCTION ${ }^{1}$}

Tot sunt speculae universi quot mentes ${ }^{2}$

In the following paragraphs I will consider a classical topic of Leibniz's philosophy, on which a broad and well-established critical literature has accumulated over the years. I

Received July 15, 2017 / Accepted January 15, 2018

Corresponding author: Antonio Maria Nunziante

Università degli Studi di Padova, via 8 febbraio 2, 35122 Padova

E-mail: antonio.nunziante@unipd.it

${ }^{1}$ Abbreviations: A = G.W. Leibniz. "Sämtliche Schriften und Briefe." edited by the Deutsche Akademie der Wissenschaften, Darmstadt-Berlin: 1923-, cited by series, volume and page; GP = "Die philosophischen Schriften von G. W. Leibniz." edited by C. I. Gerhardt. Berlin and Halle: 1875-1890. Repr. Hildesheim, 1978; DM = "Discours de métaphysique." In G.W. Leibniz. "Sämtliche Schriften und Briefe." VI 4, 1529-1588; NE = "Nouveaux essays sur l'entendement humain." In G.W. Leibniz. "Sämtliche Schriften und Briefe." VI 6; Theod. = "Essais de Theodicée sur la bonté de Dieu, la liberté de l'homme et l'origine du mal." In "Die philosophischen Schriften von G. W. Leibniz." VI, 25-365; Monad. = "Monadology." In "Die philosophischen Schriften von G. W. Leibniz." VI, 607-623. The following English translation has been used: G.W. Leibniz, Philosophical Texts, 1988; Animadversiones = G.W. Leibniz. "Animadversiones in G. E. Stahlii Theoriam medicam" in Obiezioni contro la teoria medica di Georg Ernst Stahl. Sui concetti di anima, vita, organismo.

${ }^{2}$ A VI 4 C, 1989 
will take a slightly different angle on the subject, however, as I intend to correct some of its more consolidated standard interpretations.

One of the most penetrating images that Leibniz frequently used to sum up some of his most insightful thoughts was the well-known idea of considering one and the same city from various visual perspectives. This approach is scattered throughout his writings, bearing witness - among other things - to his interest in scientific issues relating to representation, perspective and optical phenomena.

The broadly-encompassing idea of the city-image is more or less as follows: every individual substance expresses its own, original viewpoint on the world, and this unique and original perspective also represents the metaphysical "trademark" of its own individuality. This idea can be found in the earliest of Leibniz's writings, ${ }^{3}$ from his Paris years onwards, throughout the classical texts of the 1680s, and in the late Monadology. With good reason, the "multi-perspectival city" can be seen as a genuine topos of his philosophy. ${ }^{4}$

To become comfortable with such a guiding-image, we can start by reading one of the key passages contained both in the Discours de métaphysique (1686) and in the locus parallelus of the Monadology (1714):

Moreover, every substance is like a complete world and like a mirror of God or of the whole universe, which each one expresses in its own way, somewhat as the same city is variously represented depending upon the different positions from which it is viewed. (DM § 9)

Just as the same city viewed from different directions appears entirely different and, as it were, multiplied perspectively, in just the same way it happens that, because of the infinite multitude of simple substances, there are, as it were, just as many different universes, which are, nevertheless, only perspectives on a single one, corresponding to the different point of view of each monad (Monad. § 57).

Before commenting on them, however, we first need to introduce some methodological considerations. Given that the diachronic interval elapsing between the first and last occurrences of the city-image coincides with a period of nearly fifty years, and bearing in mind that Leibniz repeatedly (and radically) changed the course of his views during this lengthy period of time, interpreters are bound to wonder whether they are dealing with the same image in every case. This is tantamount to saying that we should keep in mind the huge differences in the philosophical views lying behind the different versions of the city-view (from the original one contained in the letter to Thomasius of 1668 to the mature and eventually monadological ones). We should consequently ask ourselves whether it might be more fruitful to define the specific focus of the investigation case by case, relying on a specific historical-genetic analysis, rather than seeking an overall metaphysical moral of the story.

Roughly speaking, the global sense conveyed by the city-image concerns the mirrored relationship subsisting between the city (i.e., the object) and the citizens (i.e., the subject).

\footnotetext{
3 "Hinc et patet, formam esse divisibilem, et totum in toto, produci in momento [,] esse fontem affectionum, seu qualitatum sensibilium: quae qualitates sensibiles ita se habent ad formam ipsius rei, uti se habet ad ipsum urbis situm varietas apparentiarum, quae mutato intuentis situ multipliciter variantur". See: Leibniz to Jakob Thomasius, 26 September (6 October) 1668 (A II 1, 18).

${ }^{4}$ In De plenitudine menti of 1676 we read: "there are as many different relationships with the universe as there are minds, just as the same city can be observed from different places" (A VI 3, 524). Other citations drawn from the Parisian period can be found, for example, in A VI 3, 400 and A VI 3, 573.
} 
Yet, how are such relata to be precisely understood, and what kind of epistemic contents are actually exhibited by the city's inhabitants?

While it seems reasonable to assume that Leibniz uses the city-image to induce us to reflect on the relationship between the observer-subject and the observed-world, it is by no means trivial to note - and here lies the core of the methodological issue - that it was precisely the structure of the subject-object relationship that changed radically over the years. Ontologically speaking, a monadic individual differs profoundly from the almost Aristotelian conception of individuals that Leibniz had in mind in his early writings. The material status of matter was also completely redefined by the dynamics-oriented reform of Cartesian mechanics, which occurred from the second half of the 1670s onwards. Strictly speaking, neither objects nor subjects were the same any more, in terms of either their metaphysical feature or their epistemological conditions.

Being aware of such methodological difficulties, and taking for granted that no attempt will be made to reconstruct the history of the various different contexts implied each time by the city-image, in the following paragraphs I will simply adopt the latest point of view on the subject, referring to the multi-perspectival image under the specific constraints of the monadological lexicon. Yet, the point is that, given the very distinctive ontological features of the monadic individual substance, the most common and immediate sense of the city-image must be overturned.

If a monadic citizen can be described as composed of a tissue of internal representations (monads are supposed to be windowless), and if "there is nothing in things except simple substances, and in them perception and appetite" (GP II, 270), we need to understand what the city's inhabitants actually see, and to what extent each citizen can be sure of sharing the same representative content with others. A first problem to solve, therefore, concerns the very nature of the mirroring relationship between the observers and what they observe, which - quoting from Monadology - can be restated in the following terms:

This interconnection or accommodation of all created things to each one, and each to all the others, brings it about that each simple substance has relations that express all the others, and consequently, that each simple substance is a perpetual, living mirror of the universe (Monad. § 56).

Monads are "living mirrors" of the world. ${ }^{5}$ Or rather, each monad seems to express an entirely different universe, which is tantamount to saying that there is presumably an infinite number of different universes, each corresponding to the individual perspective taken by a single monad. But what does this really mean? ${ }^{6}$

\footnotetext{
${ }^{5}$ According to Benson Mates, the mirror thesis can be formulated as follows: "The state of any monad at any time is supposed to mirror or express the states of all the other monads at that time, as well as its own past and future states". He then adds: "Since the relation of mirroring or expressing is obviously transitive, this implies that the state of any monad at any time mirrors all states of all monads at all times. [...] It follows that every monad at every time is perceiving the whole universe of monads, in all past, present, and future states". See Mates 1986, 78. Mates also reports the main criticisms raised against this doctrine (see ivi, 78-80). On the same issue, see McRae 1976, 141; Brown 1999, 263-287, esp. 204-210; Ishiguro 1990, 151-153; Adams 1994, 220223; Mondadori 1994, 83-106, esp. 92-94; Di Bella 2005, 343-344.

${ }^{6}$ For a first introduction to the issues implicit in the notion of "point of view" in Leibniz, see: Levin 1980, 221-228.
} 


\section{2. "COMME PLUSIEURS SPECTATEURS CROYENT VOIR LA MÊME CHOSE..."7}

The inhabitants of Leibniz's city all see the same town, but by way of analogy, in the sense that each of them is looking at it from a different angle of view. They are all considering the same object, but from different visual perspectives. That is why Leibniz, in Monadology, says that there are, as it were, "many different universes".

Although things seem to be clear enough at first glance, it may still be worth posing another question: what meaning are we supposed to attribute to the sameness the observers refer to? The point might seem trivial, but it is worth giving some thought.

The above-mentioned $\$ 57$ of Monadology seems to imply that monadic individuality defines itself on the basis of its relationship with the world. Moreover, this relational monad-world affair entails that everything that is inscribed within an individual point of view (whatever it may be) makes up the furniture of what we are accustomed to calling a "world", whereas anything happening to fall outside this point of view does not count (directly, at least) as part of it. There seems to be a kind of essential link between having a point of view and the presence of a world. There also seems to be a full correspondence between an epistemic subjective condition and an ontological objective fact, in the sense that the former appears to depend on the latter: there has to be a world/universe (realisticontological condition) for us to be able to have different views on it (epistemic condition). But this is exactly where the poison lies: how can such a belief be justified? Does not the conclusion contrast too much with Leibniz's assumption of nominalism ("there is nothing in things except simple substances, and in them perception and appetite")?

To unravel the knot, let us pose the following legitimate question: are we entitled to speak of a mutual relationship? In other words, is the subjective representative content of the monadic individual actually co-extensive with the ontic-objective domain of the world? How are we supposed to interpret this internal stress between an all-encompassing subjectivity and a world that seems to collapse in the former? Does the universe simply consist in the epistemic output expressed by a monad? Was Leibniz's idealism really so coarse?

Several thorny problems are already piling up here. Let us try to list them randomly:

a) Which individuals possess a point of view? Humans, sure, but what about animals or vegetables, or artificial machines?

b) The monad-world relationship seems to be asymmetrical. Or rather, we are prepared to claim that something like a world corresponds to every individual point of view, but it is certainly wrong to conclude that the whole world is contained in a single point of view. Conversely, we might successfully argue that the universe is a collection of points of view or, more realistically, that the universe constitutes the common ground on which intersubjective perspectival contents are founded. This also seems consistent with Leibniz's own view as expressed, for instance, in the late Theodicy:

I call 'World' the whole succession and the whole agglomeration of all existent things, lest it be said that several worlds could have existed in different times and different places. For they must needs be reckoned all together as one world or, if you will, as one Universe. (Theod I § 8).

${ }^{7} \mathrm{DM}, \S 14$. 
c) Then there is the tricky issue of solipsism. If the world happens to be saturated by a single individual perspective, how can we be sure: (I) of the existence of other points of view; and (II) of some kind of correspondence between one individual's representative mental content and the real world outside?

d) In what sense should we perceive individuals as being distinguished by their "points of view"? How can a modal distinction, which refers to the mode of an intentional representational perspective, possibly give rise to an ontological feature? Putting it differently: how can differences in modal perspectives be adopted as ontological constraints?

Let us try to re-examine the baseline situation by reflecting on two closely-related issues:

1. the multi-perceived city is always different - due to the private point of view expressed by each citizen;

2. the multi-perceived city is always the same - according to a common ontic correspondence.

The problem is: if I accept (1), how can I also argue for (2)? Given that in a solipsistic perspective ontic occurrences simply coincide with modal differences and given also that each viewer is fully embedded within her/his own perspective, how can one be sure that any other citizen's representation will be identical, or at least similar, to our own?

Oversimplifying, there are two completely different, although intertwined, issues at stake here: one can be labeled as the epistemic condition, concerning each viewer's mode of representation (how we refer to an object); the other could be more accurately called the "ontic" constraint, involving the real content of individual representations (what correspond to the viewer's gaze).

It seems anyway that we clearly need to add something else, because this distinction between ontic and epistemic dimensions cannot really be separated from the sensitive issue of how individuality is to be defined insofar as the whole issue of substantiality is necessarily implied here.

Let us anticipate Leibniz's solution: according to him, all individual substances represent the same stuff (the universe) and differ from each other not in the content of their vision (which is the same), but because of the way they see the same thing. They differ from each other not in what they see, but in how they see it: "res non differunt nisi modo" (A VI.3, 573) ${ }^{8}$.

The idea that individuals are modally differentiated, strange as it might look, seems to find a first point of consistency thanks to the support of some explicit textual references to it.

Individual perceptual differences rely not on their respective intentional content (taking for granted that every substance perceives the wholeness of the universe), but on the clarity, vividness or adequacy of their perceptions:

Monads are limited, not as to their objects, but with respect to the modifications of their knowledge of them. Monads all go confusedly to infinity, to the whole; but they are limited and differentiated by the degrees of their distinct perceptions. (Monad. §60)

\footnotetext{
8 "Therefore the essence of all things is the same, and things differ only modally, just as a town seen from a high point differs from the same town seen from a plain". Quod ens perfectissimum sit possibile: A VI 3, 573. For a comment on the passage in question see: Di Bella 2005, 74-76.
} 
Besides, there is an additional level of difficulty: assuming, ex hypothesi, that it is a modal factor that marks individual (hence, ontological) differences, how can we combine the statement concerning the universal interconnectedness of things (according to which each substance perceives the same entire universe) with the idea that individuals' representative states differ internally? In other words, in a world consisting of purely reflecting perceptual states, where do we place the immanent root of the individual distinction? It seems that Leibniz's theory falls almost unavoidably prey of circularity, insofar as the representative content of the city-viewers is but a function of a modal perspective, which is based in turn on the sameness of a single existing universe and the latter simply consists of the sum of a large number of perceiving individual substances ("there is nothing in things except simple substances, and in them perception and appetite").

However difficult it may appear, the path taken by Leibniz seems to be precisely this, but to appreciate his solution we first need to acquire some further conceptual tools.

\section{3. "SYMPNOIA PANTA"}

First of all, we must try to get rid of the cumbersome issue of solipsism. As mentioned before, the most radical objection to the hypothesis of a real congruence between private views and corresponding objective worlds seems to be the one that denies the possibility of transcending the subjective and perspectival nature of one's own representation. In other words, once a citizen-viewer has climbed the tower in the city's main square to contemplate its surroundings, how one can be sure of a consistency between what she perceives (the representational content of her mind) and the actual city around her? If the world we normally see and interact with is shaped entirely by our internal perspective, how can we possibly count on there being an "outside" that corresponds to the "inside"?

It is important to emphasize this problem, because the image of "windowless monads" has often been misunderstood, prompting misleading (but nonetheless obstinate) interpretations. Leibniz considers the hypothesis of a "solitary monad", trying to imagine a situation in which there is only a single perceiving monad other than God who had created it. To return to the example of the city, we could therefore imagine a single viewer looking at the outside world, and this "outside" appearing to her as the most normal she has ever seen: nothing of what she sees, feels or perceives has any real ontological consistency, and yet her ordinary perception of the world continues to be the result of a well-ordered set of perceptions (so well-ordered that it simply seems to be "true", or "real", to all intents and purposes).

There would not be in fact any deception of rational creatures even if everything beyond phenomena did not correspond exactly, even if there were nothing: as if some mind were to find itself alone. ${ }^{9}$

The problem is intriguing, logically undecidable, and related in some way to the issue concerning the lack of distinction between dream and reality (which has to do with the

\footnotetext{
9 "Deceptio autem creaturarum rationalium nulla foret, etsi Phaenomenis earum non omnia extra ipsas exacte responderent, immo si nihil: veluti si mens aliqua sola esset”. To Des Bosses, 21 April 1715: GP II 496. On the hypothesis of the solitary monad, see also GP IV, 519.
} 
old topic of Descartes's evil genius): if what we are accustomed to calling "world" were but the content of a well-ordered dream, how could we get on with it? Would we not be perpetually destined to fail?

Leibniz makes no logical objections. If it were all a well-established dream, everything would continue to appear to us as it is (and therefore "real") - providing that we keep our mental order of representations, and our corresponding physiological (past, present and future) reactions unchanged. Assuming a solitary monad, the structure of what we call "world" would therefore still appear to us exactly as it did before this kind of idea. The whole issue consequently seems to shift in meaning and raises a pragmatic question: why should we assume such an extreme hypothesis that, once accepted, will have not the slightest impact on the content of our mental life, or on our concomitant bodily reactions, or environmental interactions? If nothing really changes in our ordinary perception of the (internal and external) world, or in the epistemological, ethical or ontological implications it carries out, why bother to introduce such a hypothesis? In spite of its apparent radicalism and undeniable fictional charm, the idea of a solitary monad ultimately proves to be unproductive and devoid of theoretical or practical consequences. ${ }^{10}$

From a theoretical standpoint, "reality" essentially means "order". It is as if there were pillars supporting our mental life that need to be valid for every possible world: the possibility of establishing causal links, of reasoning in terms of identity and contradiction, the principle of economy, etc., and they all concur to determine the mind's ability to represent a world. Indeed, there is an invisible network of principles that are (if I may use the expression) consubstantial with the very notion of "world". As Leibniz put it, individuals can be (maybe) changed, but rules cannot. Perceiving a "world" amounts to respecting an essential nomological dimension that is extra rem, as it were, in the sense that we are not allowed to choose or use it at will, but we are somehow entitled to say: "outside the law, outside the world".

The solitary monad hypothesis is therefore dull (and Leibniz himself said repeatedly that he used it only as a fictional tool ${ }^{11}$ ), not because it cannot be logically supported, but because it is poor in theoretical consequences and devoid of practical significance (insofar as it requires the acceptance of a whole pre-existing order). The problem lies not so much in the relationship between dreams and reality, or in the alleged monasticism of solitary monads, but rather in how to establish the set of rules needed for the appearance of something like a "world" to be possible. ${ }^{12}$

To say: "Look, the square you're looking at is actually a figment of your imagination!" hardly serves to clarify the procedural dimension of perceptions, nor does it even begin to explain why I am seeing something instead of nothing.

\footnotetext{
${ }^{10}$ Serious doubts about the real consistency of the "solitary monad" were raised by Hide Ishiguro: "For if the set of predicates which makes up the description of an individual concept includes relational predicates or somehow expresses relational properties, then these predicates would not be true of that individual in a universe in which there were nothing except that individual substance and God (and hence the set would not give the concept of the individual)". See Ishiguro, $1990^{2}: 150$. Similar doubts were also raised in Mondadori, 1994: 97.

11 " [...] it is clear that this pre-established harmony destroys such a fiction, which is a metaphysical possibility, but which does not accord with the facts and their reasons" (GP IV, 530).

12 "Interim Monades non existunt solitariae. Sunt Monades, non Monachae", in Leibniz, "Textes inédits d'aprés les manuscrits de la Bibliotheque provinciale de Hanovre", vol. I, 395.
} 


\section{Private PERSPECTIVES AND CONCEPTUAL SOlUtions}

The point is rather different. Solipsism is not simply about denying the existence of something like an external world (as may happen in its roughest versions). The heart of the matter lies in understanding how it is possible from a private all-encompassing perspective to share other different perspectives, and how these perspectives can refer all together to one and the same world.

It is not difficult to accept the idea that worlds individually-perceived can differ modally (many perspectives = many different worlds). What is hard to explain is how this multi-perspectival insight can be matched with a shared (ontic) ground of reference. The image of the multi-perceived city, and of its mirroring citizens, does not convey only the idea that each individual substance reflects the entire universe from its own private perspective, but rather that each substance mirrors exactly the same universe as the others. $^{13}$

This is the hurdle that we need to overcome, bearing in mind that for the doctrine of the complete concept each individual is not like a world, but is a world. There are at least three essential doctrinal references contained in the mirror thesis.

1) There is the idea that each individual is actually a representative world, and this is linked not only to the image of the windowless monad, but also to the doctrine of the complete concept which, though not mentioned explicitly by Leibniz in Monadology, remains in the background like a sort of a general epistemic requirement. The monads' lack of openness thus proves to be a function of their completeness: a monadic-individual world needs no windows because it already contains them all.

2) There is the question of the universal interconnection "of all created things to each other", the communication that extends itself "to any distance whatsoever" and the interconnection "of all matter in the plenum" (references are to $\S \S 56-57$ and 61-62 of Monadology).

3) Finally, there is the specific manner in which Leibniz believes this universal interconnection can be accomplished. That is, the distinction between "things" and "concepts", ${ }^{14}$ whereby complete concepts are necessarily linked to each other and, on the other side, organic matter (materia secunda) consists of an endless enchaînement of "folds", the counterpart of which is none other than the perceptual level embedded in the doctrine of "small perceptions".

Needless to say, numerous other topics could be added, including the soul-body relationship (the so-called "psychophysical expressionism"), universal harmony, the logical status of expressions, and many more. To avoid getting entangled in too many threads, however, I prefer to start by focusing on the third of the above-listed items. From there on, everything should become clearer.

Returning to the complete concepts, in fact, and using a not entirely appropriate image, we could say that individual substances are like storylines that develop sequentially and turn out to be mutually connected, albeit indirectly. A single city-viewer is defined by an endless series of determinations. The whole story of her life is summed up in her present gaze, as well as

\footnotetext{
${ }^{13}$ The idea that each substance mirrors the same universe was underscored by Mondadori 1994, 83.

${ }^{14}$ On the "new alliance" instituted by Leibniz between "things" and "concepts", and on their difficult relations, see the analysis in Di Bella 2005, 197-237.
} 
aspects of which she is unaware, in the sense that escape her powers of recall, and belong as it were to the subconscious dimension of the psychic life.

In a nutshell, the complete concept represents a system of correlated determinations that, although can only be partially known by the subject, nonetheless contains the most intimate essence of its individuality. Quoting Leibniz:

The complete concept is that starting from which all the predicates of the same subject can be demonstrated, or that which expresses the whole nature of the subject, just as the concept of Alexander the Great expresses the king, the winner, the disciple of Aristotle, etc. ${ }^{15}$

Using technically more appropriate terminology, we could say that the notio completa, contains a whole set of predicates corresponding to the internal modifications of an individual; and, since we are dealing with states of perceptual nature, the actual substantiality of an individual consists of the totality of her internal representative states. ${ }^{16}$ Due to its completeness, besides, the notio completa seems to refer to the relationships that each city-viewers entertain with her peers, as well as with the surrounding environment. The complete concept thus encompasses not only the "internal" determinations of a substance (like the memory of a landscape, or the perception of a pleasant sea view), but also those "external" thereto (like the fact of perceiving, albeit confusedly, other people's perceptions), which pertains to the so-called "biosphere" of an individual. It is for this very reason that the individual essence of each city-viewer in some way contains and expresses the whole universe ("totum universum"). ${ }^{17}$

This is one of the most characteristic aspects of Leibniz's thinking and has always attracted the scholars' attention (as well as innumerable controversies), because it is as if the whole universe were concentrated in the individuality of a point of view. Countless references are condensed in a single city viewer, including, for instance, the presence of other present, past or future citizens. As we will see in a moment, such relatedness indirectly builds the essential framework of a conceptual-holistic feature that explains the metaphysical/ontological dimension of individuality. This latter can be grasped only by referring to a close, yet infinite, system of predicates, and it is only by fulfilling such an epistemic step that the metaphysical/ontological individuality of each city-viewer can finally be unveiled.

This is where things become more and more complicated, however. If the individual essence, in fact, is made up of a series of internal predicates, there is no way to draw from here any useful inferences regarding the ontological status of external things, because by definition an individual is a close system of internal references. ${ }^{18}$ This is the raising point of solipsism that, on closer inspection, turns out to be but a problematic matter of relations in the sense that what is at stake here concerns precisely the way in which an epistemic constraint (the infinite, yet close system of relations) can eventually be changed into an ontological feature (concerning the real nature of the individual).

\footnotetext{
${ }^{15}$ A VI 4 A, 625 - Definitiones notionum metaphysicarum atque logicarum.

${ }^{16}$ See Mugnai 2001, 51.

17 "Res completa seu substantia ejus cujus completa notione omnia quae in ipsa unde et omnia aliena seu totum universum". Tabula notionum praeparanda, A VI 4 A, p. 631. On the problem of the status of relations in the philosophy of Leibniz (Mugnai 1992).

${ }^{18}$ Di Bella 2005, 345-46.
} 
Scholars have long felt the need to distinguish between different levels of the complete concept, namely between "intra-monadic" and "inter-monadic" relations: the former refer to the relationships between the individual and her representative internal states; the latter to the interpersonal relationships entertained with other monadic individuals (e.g. Alexander relates to his father, to his teacher Aristotle, and so on). (Mugnai 1992, 14-15)

The question thus becomes: if the representative dimension of the individual is inescapable, it seems unavoidable that the complete notion of individuality "needs" (indiget) - at least conceptually - the presence of other concurrent and complete notions (like those of other citizen-viewers) in order to be staged. The key-expression here is "at least conceptually", because it is right here that solipsism falls apart:

Something more is required in the definition of a modification than the mere necessity of another concept, and 'being contained in' (a quality that is common to both properties and modes) is more than needing something else. In my opinion, there is nothing in the world of created substances which does not need, for its perfect concept, the concept of every other thing, since each thing involves the others in such a way that, supposing it did not exist or were otherwise, all things in the universe would be different from what they now are. ${ }^{19}$

Solipsism fails to convince because, in order to give an adequate account of individuality, we need to include many other actors on the world. To stage our own representations, so to speak, we need other complementary and accessory representations to be enacted. We also need all these other representative states to be compatible with our own story, with the kind of narrative plot that we are developing, more or less consciously. ${ }^{20}$ The crucial point is that an individual representation cannot go on stage unless there are other representing-bearers and, if none actually exist, we need them to exist conceptually at least. It goes without saying that such other representing-bearers must be mutually compatible too, because it has been convincingly reported that to speak of a "world" actually means to refer to some set of reciprocally "compossible" complete concepts. ${ }^{21}$

The issue is admittedly by no means clear and it is far from having been unequivocally solved. It is evident, nonetheless, that - if this were the case (at least in hypothesis) - then solipsism would collapse, if not ontologically, at least epistemologically. Even if it cannot be taken for granted that things work like that, it seems plausible to admit that in Leibniz we simultaneously have two distinct notions of complete concept: one referring only to intramonadic relations; and a second, broader one, that refers to inter-monadic ones (Mugnai 2001, 180-81). This is tantamount to saying that it is one thing to speak of individuals (which are basically unrelated in their internal determinations) and another to talk of the corresponding "complete concepts" (which are mutually integrated and infinitely reflecting).

Now, returning to the city image, we can draw a provisional conclusion: if it is true that we can never escape our own perspectival point of view (because doing so would be like stripping off our skin), it is also plausible - on a conceptual and epistemic level at

\footnotetext{
${ }^{19}$ See GP II, 226. Benson Mates has called scholars attention to this and other similar passages (A VI 6, 229). See Mates 1986, 220.

${ }^{20}$ As Di Bella rightly points out: "individuals are conceivable, hence individual concepts possible, only by assuming their being inserted in an infinitely complex network of other interconnected individuals" (Di Bella 2005, 344). See also Mondadori 1978, 167; Mates 1986, 75.

${ }^{21}$ Di Bella 2005, 344.
} 
least - that the very presence of other concomitant perspectives emerges as an essential feature in the unfolding of our own narrative dimension.

\section{LONG-RANGE COMMUNICATION}

The issues to be solved are not over yet. We said in item (3) in the previous section that the universal interconnectedness of things charts a sort of dual course in Leibniz's thought: we have the logical-epistemic front plus a multi-variegated front of findings composed of cosmology, physics, dynamics and biology, which trespasses into a further body-physiological field of inquiry to which it is time to turn our attention. Admittedly, another great peculiarity of Leibniz's thinking lies in his capacity to bring together different areas of inquiry: according to the law of universal harmony, physics can also be interpreted as an essential counterpart of the logical world, organic physiology serves as a counterpart of mental life, and so on, right down to the minutest detail.

Starting from his early writings (the Hypothesis physica nova at least), Leibniz defends the theory of the density of matter, according to which even the tiniest particle of matter contains "mundi in mundis in infinitum". ${ }^{22}$ Matter is dense. It can be divided into an infinite number of parts, and the very concept of a continuum represents a sort of ultimate challenge for the young philosopher's mind. He seems, in fact, to realize (around the Parisian years, 1672-1676) that matter would fall apart if it really were infinitely divisible. Bodily substances would be like "arena sine calce" if the paradoxes of the continuum were applied directly to matter. ${ }^{23}$ On the other hand, as Leibniz pointed out in the Pacidius Philalethes (1676), physical matter is not made up of points, or indivisible elements like atoms. It is contiguous, being currently divided into an infinite number of discrete structures, or "folds" (which are also mentioned in $\$ 61$ of Monadology).

So, this is how things look: in the realm of natural bodies divisions are never entirely homogeneous and the divided bodily parts never form topologically equivalent shapes; matter is made of blocks, leaps, discrete parts, and even its tiniest fold represents a dynamic process that, in the case of organic bodies, implies a number of physiological effects. It is also, and in some ways most importantly, from this background of physics and animal physiology that, little by little and with endless readjustments, the mature Leibniz comes to elaborate his own original doctrine of "small perceptions", which represents the soul-psychic counterpart of the endless folding of organic matter. ${ }^{24}$

The result is a complex picture in which each portion of matter is filled up with monads, and therefore endowed with perceptual activity. At the same time, such physical and metaphysical framework does not imply that matter can be considered as animated

\footnotetext{
${ }^{22}$ See Hypothesis Physica Nova, A VI 2, 241. The influence exerted by the Micrographi of the time is naturally not foreign to this kind of hypothesis. The discovery and widespread use of the microscope determined a real revolution in the way matter was considered. Leibniz had always been interested in this type of study and he gradually integrated his findings through a kind of implementation with his reflections on the nature of the infinitesimal, on the thematization of the conceptual pair indivisibile/continuum, with the "dynamic" breakthrough, and so on. On these topics, see Wilson 1995; Duchesneau 1998.

${ }^{23}$ Cf. Arthur 1998, 25-45.

${ }^{24}$ Needless to say, this kind of continuistic interpretation should not be over-emphasized: the Leibniz of the Pacidius is not yet the Leibniz of the Monadology. But it is difficult to understand the one without having prior knowledge of the problems examined by the other.
} 
per se. Leibniz often refers to the fish-farm model: although a pond may be populated by living elements, this does not mean that the pond itself is alive:

Although there is indeed no part of matter in which it is not hiddenly present some living or organic body, notwithstanding the mass itself does not happen to be alive or animated, as we already pointed out with the example of the fish-nursery that can abound with animals, but it is not in itself an animal. (Animadversiones, 32)

Each body actually consists of a flow of bodies: matter (i.e. secondary matter) is but a steady process in which dissipation and reintegration mutually concur. As long as this process is balanced, the body remains alive, but when bodily particles are dissipated more and more, life is slowly extinguished, leaving behind a sort of persistent echo. ${ }^{25}$

It is therefore evident that such a complex and multi-layered corporeal physiology eventually helps to crack the solid wall of solipsism from within. The universal interconnectedness of things is justified on the grounds of the infinite organic folds that are simultaneously associated by Leibniz with minimal forms of perception. An extremely powerful holistic framework is hence produced, displaying a perpetual game of psychic and corporeal correspondences for the everlasting glory of God.

The physical universe seems, in fact, to be crossed by a parallel flow of infinitely reflecting and unfolding physical events as well as mental states. This is probably the most difficult point for us to understand: the way in which the physical and psychological dimensions come together, also combining with the logical grounds of the complete concepts, and giving shape to a world of individual living substances that are correlated and autonomous at one and the same time.

Strange as it might seem, only this profoundly articulated view in which mental, physical, physiological and logical models are seen as intertwined can ensure, in Leibniz's world, that the multi-perceived city is really "the same" for all of us, and not only via analogy. ${ }^{26}$

\section{CONCLUSION}

Everything is interconnected and the whole universe is animated by a perceptual stream of activity that defines the deep (often subconscious) nature of individuals as well as their environmental relationships. Small perceptions mark the minimum distance subsisting between the organic physiology of the body and the mental life of the individual. Such distance never shrinks: bodily movements governed by physiology and

\footnotetext{
${ }^{25}$ It is common knowledge that, in Leibniz's view, death and birth do not coincide with what is macroscopically observable.

${ }^{26}$ In a note in the margin of proposition 12 of Spinoza's Ethica (quoted by the editors of A VI 4), Leibniz comments: "The world is one but minds are many". This passage is significant not only because it marks a particularly subtle and interesting comparison with Spinoza (which is beyond the scope of the present contribution), but also because it ends with a reference to the multi-perspectival dimension of the "city", confirming yet again the importance that Leibniz attributed to this image. The passage, which I quote in its entirety in the original Latin version, reads as follows: "Ideae non agunt. Mens agit. Totus mundus revera est objectum cujusque mentis, totus mundus quodammodo a quavis mente percipitur. Mundus unus et tamen mentes diversae. Mens igitur fit non per ideam corporis, sed quia variis modis Deus mundum intuetur ut ego urbem" (A VI 4 B, 1713).
} 
perceptual representations instantiated by the soul run harmoniously in parallel, never mingling with one another.

This also means that, although every minimal physiological variation is always accompanied by the simultaneous emergence of some representative state of the soul (and vice versa), any form of efficient mechanical causality is banished. The mirror image which turns out to be more than a mere metaphor - mainly illustrates the idea that such processes of correspondence are kept indefinitely and that harmoniously constitute the most profound structure of the individual - representing principles of both nature and grace, to paraphrase from one of Leibniz's latest works. Ultimately, the mirror-image seems to be enhanced in the monadological doctrine: while its general sense has always focused on the relationship between the individual and the world, the monadological turning point undertaken by Leibniz greatly enhances its previously undetected theoretical power.

A final point remains to be clarified. In the opening paragraphs of this essay, in describing the various problems to be faced, we wondered which subjects in Leibniz's world possess a point of view. The issue is complex and, to develop it, we should examine some further references, concentrating on the distinction between "artificial aggregates" and "natural machines". ${ }^{27}$ Briefly, we can now say that the capacity to express a point of view, in its broadest sense, is characteristic of living beings belonging to the vegetable kingdom (albeit with some degree of uncertainty), ${ }^{28}$ to the animal kingdom and, of course, to human beings. ${ }^{29}$

In the Discours de métaphysique, which makes much use of the city-image, we can find a very interesting consideration on this topic. Generally speaking, being endowed with unitary forms of perception is a peculiar trait of living beings, because life itself is defined as a form of self-maintenance, which is accomplished by displaying perceptual states. ${ }^{30}$ Perception, therefore, is that fundamental tool by means of which animals are able to survive by actively selecting everything that tends to increase their own vital energy, while removing and avoiding all harmful obstacles. ${ }^{31}$

The potentially diversifying ontological factor among different living species lies in the quality of their perceptions, in the sense of the degree of clarity of their environmental

\footnotetext{
${ }^{27}$ On the topic of the organicity of the living being and the characteristics that distinguish it from "organica artificialia", see Schneider 1985, 335-352, esp. 346-351; Duchesneau 1998, 315-372; Michel Fichant 2003, 2 16; Nunziante 2004, 203-216, esp. 207-214; Nachtomy 2007, 203-230.

${ }^{28}$ Plants probably have some perceptive capacity, but Leibniz is not entirely sure of this: "I judge that plants and animals are probably animated, but I still cannot state this with certainty, because I cannot have an intimate experience of it"; see A VI 4, B, 1669. Still more specifically on the souls of plants: "I dare not guarantee that plants do not have soul nor life nor substantial form; although a part of the tree, planted or grafted, can produce a tree of the same species, it is possible that it is joined to a seminal part which already contains a new plant; as perhaps there are already living animals, although tiny, in the seed of animals [...] I therefore still dare not guarantee that only animals are alive and endowed with substantial form. See Leibniz an Arnauld (30 april 1687), GP II, 92.

${ }^{29}$ After a youthful period of doubt, Leibniz started towards the end of the 1670 s to recognize the need to attribute souls to animals.

30 "Corpus vivens est Automaton sui perpetuativum ex naturae instituto" (Tabula notionum praeparanda: A VI 4 A, 633); or again: "Machina sese sustentans et sibi similem producens" (Genera terminorum. Substantiae: A VI 4 A, 568).

31 "Perceptionis gratia sunt organa sensuum; procurandae perceptionis sive actionis gratia sunt organa Motus. Ambo debeant conservari in continua operatione aut operanti promtitudine quod fit tum remotione impedientium, tum additione convenientium". Cfr. Leibnitz 1996, 212.
} 
representations. According to Leibniz, there is, however, an insurmountable gap between animals and human beings ("souls" and "spirits"), as highlighted in the $\S 36$ of the Discours:

Although all substances express the whole universe, nevertheless the other substances express

the world rather than God, while minds express God rather than the world. (DM §36).

If perception generally has to do with the capacity to "express a world" by mirroring the surrounding universe, the human mind adds to this a reflexive ability, insofar it is capable of detecting in the mirrored image a reflection of its own individuality. In this sense, the landscapes and buildings that the city-viewer contemplates are not only a matter of aseptic representation: they are sensed and experienced (albeit largely unawares) as forming part of the viewer's own individual story.

If the difference between substances with and without intelligence is "just as great as the difference between a mirror and someone who sees" (DM §35), the peculiarity of individual substances eventually consists in their ability to recognize their own individuality in the whole spectrum of nature or, as written in $\$ 83$ of Monadology, in the fact of being "images of the divinity itself". 32

It is a kind of "authorship" that is ultimately shared by individuals and the almighty Creator of the universe: just as God is the very author of nature, so too spirits are endowed with a jurisdictional authority (however tiny), in the sense that each spirit recognizes its own universe, and marks with a sign of its own individuality the world in which it lives, and in which its individual story eventually finds expression.

\section{SOURCES}

Leibniz, G.W. "Sämtliche Schriften und Briefe", edited by the Deutsche Akademie der Wissenschaften. Darmstadt-Berlin: 1923.

“Die philosophischen Schriften von G. W. Leibniz", edited by C. I. Gerhardt. Berlin and Halle: 1875-1890. Repr. Hildesheim, 1978.

"Discours de métaphysique". In G.W. Leibniz. "Sämtliche Schriften und Briefe." VI 4, 1529-1588

"Nouveaux essays sur l'entendement humain”. In G.W. Leibniz. "Sämtliche Schriften und Briefe.” VI 6.

"Essais de Theodicée sur la bonté de Dieu, la liberté de l'homme et l'origine du mal". In "Die philosophischen Schriften von G. W. Leibniz.” VI, 25-365.

"Monadology". In "Die philosophischen Schriften von G. W. Leibniz". VI, 607-23.

Leibniz, G.W. Philosophical Texts, translated and edited by Roger S. Woolhouse and Richard Francks. New York: Oxford University Press, 1988.

Leibniz, G.W. "Textes inédits d'aprés les manuscrits de la Bibliotheque provinciale de Hanovre", edited by Gaston Grua, 2 voll. Paris: PUF, 1948

Leibniz, G. W. "De scribendis novis medicinae elementis". In Corpo e funzioni cognitive in Leibniz, edited by Enrico Pasini, 212-17. Milano: Franco Angeli 1996.

Leibniz, G.W. "Animadversiones in G. E. Stahlii Theoriam medicam”. In Obiezioni contro la teoria medica di Georg Ernst Stahl. Sui concetti di anima, vita, organismo, edited and translated by Antonio-M. Nunziante, 22-121. Macerata Quodlibet, 2011.

\footnotetext{
32 "Among other differences which exist between ordinary souls and minds, some of which I have already noted, there are also the following: that souls, in general, are living mirrors or images of the universe of creatures, but that minds are also images of the divinity itself, or of the author of nature, capable of knowing the system of the universe, and imitating something of it through their schematic representations of it, each mind being like a little divinity in its own realm". See Monadologie, $\S 83$.
} 


\section{REFERENCES}

Adams, Robert M. Leibniz: Determinist, Theist, Idealist. New York and Oxford: Oxford University Press, 1994. Arthur, Richard T.W. "Infinite, Aggregates and Phenomenical Wholes: Leibniz's Theory of Substance as a Solution". Leibniz Society Review 8 (1998): 25-4

Brown, Stuart C. "The Proto-monadology of the De Summa Rerum". In The Young Leibniz and His Philosophy, edited by Stuart C. Brown, 263-287. Dordrecht, Boston and London: Kluwer, 1999.

Busche, Hubertus. Leibniz' Weg ins perspektivische Universum. Eine Harmonie im Zeitalter der Berechnung. Hamburg: Meiner, 1997.

Di Bella, Stefano. The Science of the Individual: Leibniz's Ontology of Individual Substance. Dordrecht: Springer, 2005.

Duchesneau, François. Les modèles du vivant de Descartes à Leibniz. Paris: Vrin, 1998.

Fichant, Michel. "Leibniz et les machines de la nature". Studia Leibnitiana 35 (2003): 1-28

Ishiguro, Hide. Leibniz's Philosophy of Logic and Language. Cambridge: Cambridge University Press, $1990 .^{2}$

Levin, Margarita R. “Leibniz's Concept of Point of View”. Studia Leibnitiana 12 (1980): 221-28.

Look, Brandon. "On Monadic Domination in Leibniz's Metaphysics". British Journal for the History of Philosophy 10 (2002): 379-99.

Mates, Benson. The Philosophy of Leibniz. Metaphysics and Language. New York and Oxford: New York University Press 1986.

McRae, Robert F. Leibniz: Perception, Apperception and Thought. Toronto: University of Toronto Press, 1976

Mondadori, Fabrizio. “A Harmony of One's Own and Universal Harmony in Leibniz's Paris Writings”. Studia Leibnitiana Supplementa 18 (1978): 151-168.

Mondadori, Fabrizio. "Mirrors of the Universe". Studia Leibnitiana, Sonderheft 22 (1994): 83-106.

Mugnai, Massimo. "Leibniz Theory of Relations". Studia Leibnitiana, Supplementa 28 (1992).

Mugnai, Massimo. Introduzione alla filosofia di Leibniz. Torino: Piccola Biblioteca Einaudi, 2001.

Mugnai, Massimo. "Leibniz on Individuation: From the Early Years to the 'Discourse' and Beyond". Studia Leibnitiana 33, 1 (2001): 36-54

Nachtomy, Ohad. Possibility, Agency, and Individuality in Leibniz's Metaphysics. Dordrecht: Springer 2007.

Nunziante, Antonio M. "Corpus vivens est Automaton sui perpetuativum ex naturae instituto. Some Remarks on Leibniz's Distinction between Machina naturalis and Organica artificialia". Studia Leibnitiana, Sonderheft 32 (2004): 203-216.

Phemister, Pauline. Leibniz and the Natural World. Activity, Passivity and Corporeal Substances in Leibniz's Philosophy. Dordrecht: Springer 2005.

Piro, Francesco. Spontaneità e ragion sufficiente. Determinismo e filosofia dell'azione in Leibniz. Roma: Edizioni di Storia e Letteratura, 2002.

Schneider, Martin. "Leibniz über Geist und Machine”. Philosophisches Jahrbuch 92 (1985): 335-52.

Tomasi, Gabriele. "What is Person? Some Reflections on Leibniz's Approach". Studia Leibnitiana, Sonderheft 32 (2004): 257-82.

Wilson, Catherine. The Invisible World. Early Modern Philosophy and the Invention of the Microscope. Princeton: Princeton University Press, 1995.

\section{LAJBNIZOVA TEZA O OGLEDALU. SOLIPSIZAM, LIČNE PERSPEKTIVE I KONCEPTUALNI HOLIZAM}

Jedna od simboličkih slika kojoj Leibniz neprekidno poverava sintezu svoje filozofije tiče se ideje o posmatranju jednog istog grada iz različitih vizuelnih perspektiva. Takva slika prožima Leibnizovo pisanje $i$ jasno odražava filozofovo interesovanje za pitanja u vezi perspektive kao optičkog fenomena. Stanovišta stanovnika grada mogu se zbog toga uporediti sa ogledalom koje odražava neke druge delove stvarnosti. Ali šta grad-gledaoci stvarno vide? Da li svi vide istu stvar? I pod pretpostavkom mnogobrojnih tačaka gledišta, kako kako možemo biti sigurni da dele isti reprezentativni sadržaj? Rad ovde pokušava da ponudi moguće tumačenje ove teme $i$ povezivanjem različitih $i$ nekako nedovoljno zastupljenih Leibnizovih doktrina zajedno.

Ključne reči: Leibniz, um, solipsizam, perspektive, percepcija, obrazovanje holizam. 